\title{
Kształtowanie świadomości ekologicznej mieszkańców wsi poprzez działalność informacyjną lokalnych władz i instytucji
}

\section{Wstęp}

Warsztatem pracy każdego rolnika jest gospodarstwo będące fragmentem określonego środowiska przyrodniczego. Każdy świadomy tego faktu gospodarz powinien czuć się przyrodnikiem - praktykiem i z wielką troską dbać o swoje miejsce pracy, zapewniając tym samym trwałe i bezpieczne jego użytkowanie. Przez analogię można postawić pytanie, czy w interesie rzemieślnika leży degradowanie własnego warsztatu produkcyjnego, zapewniającego podstawy egzystencji jego rodziny? Odpowiedź wydaje się oczywista.

Swiadomość materialnej wartości gospodarstwa rolniczego to dziś stanowczo za mało. Ważne jest także przeświadczenie o innych walorach, których bezpośrednio nie da się przeliczyć na pieniądze, takich jak piękno krajobrazu i różnorodność tworzących go elementów, czystość i ekologiczne bezpieczeństwo, a w końcu zapach ziemi i uprawianych na niej roślin. Ma to szczególne znaczenie w kontekście zauważanej już dziś dość wyraźnie ewolucji sposobu zarobkowania ludzi mieszkających na wsi. Poszerza się grupa rolników, którzy dodatkowych źródeł dochodu szukają nie w bezpośredniej produkcji roślinnej czy zwierzęcej, ale w organizacji ruchu turystycznego. We wsiach położonych w malowniczym krajobrazie, gdzie istotne z punktu widzenia zdrowia i rekreacji człowieka parametry środowiska mają wysoką wartość, powstają rodzinne hoteliki, a produkcja dostosowywana jest do potrzeb i wymagań odwiedzających gospodarstwo gości.

Rolnictwo jest sektorem gospodarki całkowicie uzależnionym od środowiska przyrodniczego i jednocześnie w ogromnym stopniu przekształcającym go. Ciągle poszukiwane są sposoby zmniejszenia siły degradującego oddziaływania 
tej gałęzi gospodarki na przyrodę. Proekologiczne kierunki rozwoju wsi popiera także Unia Europejska ${ }^{1}$.

W Planie Rozwoju Obszarów Wiejskich nacisk położony jest na upowszechnianie zasad Zwykłej Dobrej Praktyki Rolniczej. Oznacza to przestrzeganie standardów odnoszących się do racjonalnej gospodarki nawozami, ochrony wód, gleb, cennych siedlisk i gatunków występujących na obszarach rolnych. Akcentuje się w nim potrzebę ochrony krajobrazu oraz utrzymanie czystości i porządku w gospodarstwie. Określone w planie minimalne wymagania są zróżnicowane dla poszczególnych krajów UE, co wynika ze stopnia dostosowania funkcjonującego w nich rolnictwa do wymogów ochrony środowiska oraz uzależnione jest od poziomu świadomości ekologicznej mieszkańców wsi.

W celu zachęcenia rolników do proekologicznego wysiłku, wprowadzono na wieś programy rolno-środowiskowe. Polegają one na finansowym premiowaniu działań prowadzonych na terenie gospodarstw poprzez system dopłat oraz na intensywnej edukacji, którą należy uznać dziś za najważniejsze narzędzie w ochronie przyrodniczego środowiska. Efektem skutecznej edukacji powinno być powszechne stosowanie się do zasady: „Uprawiać, nie niszcząc ziemi, żywić, nie szkodząc konsumentom"2. Ta bardzo prosta, ale jednocześnie bogata w treść myśl przypomina rolnikom, że w ich codziennej pracy tak łatwo jest przekroczyć zasady moralne. Poprzez źle wykonane zabiegi agrotechniczne degradacji ulega gleba, a nieumiejętne lub umyślnie niewłaściwe posługiwaniu się chemicznymi środkami produkcji, dla uzyskania osobistych korzyści, szkodzi konsumentom i może nie od razu, ale powoli wpływa na pogorszenie ich zdrowia i prowadzi do śmiertelnych chorób, które określa się mianem cywilizacyjnych. Wobec faktu lawinowego wzrostu ich liczby, świadomość nieuczciwej działalności produkcyjnej powinna niepokoić sumienia niewłaściwie postępujących producentów rolnych, szkodzących konsumentom i zatruwających przyrodniczy warsztat produkcyjny.

W mentalności rolników wiele można zmienić poprzez działania informacyjne i edukacyjne prowadzone przez urzędników gmin, pracowników ośrodków doradztwa, zarządów parków krajobrazowych, organizacji proekologicznych, mających do tej pracy odpowiednie przygotowanie. Są to ważne zadania, mające umocowania prawne, zapisane często w społecznej misji i statutach organizacyjnych, wchodzące w zakres systemu nieformalnej edukacji środowiskowej społeczeństwa (rys.1). Wykorzystanie internetu, jako nowoczesnego i lubianego medium informacyjnego może okazać się w tym zakresie bardzo skuteczne.

\footnotetext{
Plan Rozwoju Obszarów Wiejskich.

BĄKOWSKI J., Ekologiczna i integrowana produkcja warzyw w świetle dyrektywy Unii Europejskiej. W: Jabłońska Ceglarek R., [red.]: Proekologiczne metody uprawy warzyw. Zeszyty Problemowe Postępów Nauk Rolniczych, zeszyt 466. PWN, Warszawa 1999.
} 


\section{Założenia metodyczne}

Celem pracy było sprawdzenie, czy samorządy gminne wschodniego Mazowsza umożliwiają mieszkańcom dostęp do informacji za pośrednictwem internetu, szczególnie czy promują idee ekorozwoju, upowszechniają programy ochrony lokalnego środowiska przyrodniczego. Przyjęto założenie, że promowanie wartości lokalnej przyrody na stronach domowych gmin, może odegrać bardzo pozytywną rolę w edukacji lokalnych społeczności i motywowaniu ich do dobrej praktyki rolniczej i prośrodowiskowej aktywności.

Analizą objęto 58 stron internetowych gmin położonych w sześciu powiatach wschodniego Mazowsza: Garwolin, Łosice, Mińsk Mazowiecki, Siedlce, Sokołów Podlaski, Węgrów. Analizy i porównania wykonano w lutym 2007.

\section{Wyniki badań}

Analiza stron internetowych gmin wschodniego Mazowsza wykazała duze ich zróżnicowanie w zakresie zamieszczonych informacji o środowisku przyrodniczym i istniejących na ten temat dokumentach i opracowaniach (Tab.1). Okazuje się, że średnio co czwarta gmina w ogóle nie ma własnej strony internetowej. Często zdarza się, że strona internetowa jest założona, ale zawarte informacje nie są na bieżąco aktualizowane lub zamieszczone hasła są nieaktywne.

Na swoich stronach domowych samorządy gminne informują o prowadzonych pracach, w tym inwestycjach środowiskowych (np. o budowie oczyszczalni ścieków). Takie komunikaty oprócz informowania o etapach inwestycji i terminarzu prac, pełnią ważne zadanie edukacyjne, ponieważ instruują mieszkańców, przekonują ich do potrzeby inwestowania w ochronę środowiska dla zapewnienia społecznego i gospodarczego postępu na zasadach zrównoważonego rozwoju. Zamieszczenie dodatkowo informacji, że gmina jest beneficjentem funduszu ochrony środowiska i poprzez system umorzeń zaciągniętych kredytów, uzyskując terminowo zaplanowany efekt ekologiczny, może uzyskać pieniądze na dalszy rozwój, kształtuje pozytywną opinię o instytucjonalnych rozwiązaniach obowiązujących w państwie w zakresie ochrony środowiska, uwiarygodnia państwową i gminną politykę ekologiczną, buduje atmosferę zaufania, ekologicznego bezpieczeństwa i poczucie wspólnoty interesów.

$\mathrm{Na}$ stronach domowych tych gmin, które aktualizują na bieżąco internetowe informacje, udostępniane są różne dokumenty, np. plan rozwoju gminy (14\%), program ochrony środowiska (12\%), program gospodarki odpadami i harmonogram ich odbioru (26\%), raporty o stanie środowiska (3,5\%) (Tab.1). Obowiązkiem ustawowym każdej gminy jest ogłaszanie w biuletynie informacji publicznej (BIP) planowanych zadań inwestycyjnych i związanych z nimi przetargach. $Z$ tego zadania wywiązują się wszystkie objęte badaniami gminy. Wśród analizowanych stron internetowych nie znaleziono takiej, która zawierałaby pełny zestaw strategicznych 
informacji, w tym odnoszących się do ochrony lokalnego środowiska przyrodniczego. Na podstawie przytoczonych powyżej danych obrazujących kompletność internetowych informacji, należy wnioskować, że gminy nie wykorzystują jeszcze siły tego środka przekazu w kompleksowym informowaniu społeczeństwa, między innymi o faktach wynikających z diagnozy stanu środowiska przyrodniczego i zamiarach wiodących do jego poprawy. Upowszechnienie tej wiedzy stanowi punkt wyjścia do skutecznej edukacji środowiskowej.

Porównując strony internetowe nie można doszukać się konkretnej zasady, według której prezentowane byłyby dokumenty uchwalone przez radę gminy i obowiązujące w danej społeczności. Najlepiej prezentują się strony internetowe dużych gmin i powiatów. Można na nich znaleźć ogólny plan rozwoju gminy, programy ochrony środowiska oraz gospodarki odpadami. Gminy małe zamieszczają na stronach domowych głównie informacje o atrakcjach turystycznych i adresach gospodarstw agroturystycznych, będących wizytówką regionu.

Tab. 1. Dostępność informacji o środowisku przyrodniczym na stronach domowych gmin wschodniego Mazowsza. $(n=58)$

\begin{tabular}{|c|c|c|c|c|c|c|c|c|}
\hline & \multirow[b]{2}{*}{ 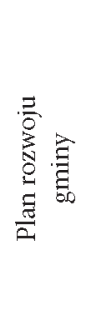 } & \multirow[b]{2}{*}{ 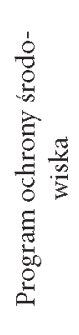 } & \multicolumn{2}{|c|}{ Gospodarka odpadami } & \multirow[b]{2}{*}{ 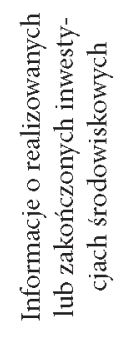 } & \multirow[b]{2}{*}{ 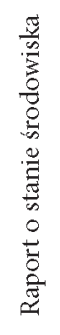 } & \multirow[b]{2}{*}{ 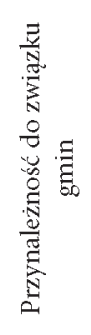 } & \multirow[b]{2}{*}{ 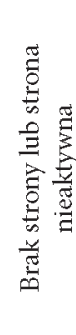 } \\
\hline & & & 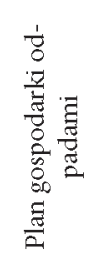 & 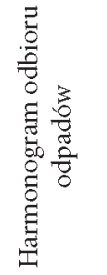 & & & & \\
\hline $\begin{array}{c}\text { Liczba } \\
\text { gmin }\end{array}$ & 8 & 7 & 9 & 6 & 13 & 2 & 9 & 15 \\
\hline
\end{tabular}

Samorządy niektórych gmin ograniczają się do podania informacji, że strategie i plany rozwoju są sporządzone i dostępne do wglądu w urzędzie. Ich zamieszczenie $w$ formie elektronicznej na stronie gminy wydaje się $z$ wielu względów, w tym edukacyjnego i sozologicznego, bardzo pożądane. Z badań Giordano (2005), dotyczących także gmin położonych na omawianym terenie wynika, że tylko jeden samorząd, kwalifikuje się pod względem szczegółowości informowania społeczeństwa przez internet do krajowej czołówki.

Niekompletność informacji internetowej może być spowodowana błędnym przekonaniem władz samorządowych o tym, że dostęp do internetu mieszkańców wsi jest jeszcze ciągle zbyt ograniczony. W dzisiejszych czasach każda instytucja dbająca o swój wizerunek powinna niezależnie od liczby osób mających dostęp do internetu w lokalnej społeczności, dbać o aktualność wirtualnej wizytówki. Należy myśleć przede wszystkim o najmłodszych mieszkańcach gmin, dla których korzystanie z sieci nie nastręcza większych kłopotów i nie stanowi żadnej bariery, 
w związku z czym to oni mogą transmitować informacje do osób dorosłych znajdujących się w ich otoczeniu i nie obytych ze współczesnymi mediami.

Istotnym elementem wpływającym na funkcjonalność i atrakcyjność strony jest możliwość utrzymywania kontaktu mieszkańców z samorządem gminy. W przypadku gmin objętych badaniami poczta e-mailowa istnieje tam, gdzie strona jest na bieżąco aktualizowana.

Uzupełniających, w stosunku do urzędów gmin, informacji środowiskowych mogą dostarczać mieszkańcom wsi Ośrodki Doradztwa Rolniczego (ODR) i inne instytucje, takie jak izby rolnicze, zarządy funduszy środowiskowych, fundacje i stowarzyszenia (np. Polski Klub Ekologiczny, Fundacja Programów Pomocy dla Rolnictwa), parki krajobrazowe czy firmy produkujące towary dla rolnictwa. Wymienione instytucje czy fundacje w sposób planowy mogą wdrażać programy ekologiczne, wspierać lub inicjować zachowania rolników przyjazne dla środowiska.

Zadaniem Ośrodków Doradztwa Rolniczego jest m.in. wspierania zrównoważonego rozwoju obszarów wiejskich poprzez popularyzowanie ekologicznych metod gospodarowania oraz przedsięwzięć dotyczących ochrony środowiska naturalnego. Ośrodki Doradztwa Rolniczego dysponują dość bogatą ofertą edukacyjną typu: szkolenia, kursy, olimpiady czy pokazy związane zarówno z przystosowaniem rolnictwa polskiego do wymagań unijnych, stałym podwyższaniem poziomu produkcji, jak i ochroną środowiska. Dla przykładu Mazowiecki Ośrodek Doradztwa Rolniczego, na luty 2007r. dla oddziału Siedlce, przygotował aż 99 propozycji związanych zarówno z ochroną środowiska w rolnictwie, jak i upowszechnianiem kultury ekologicznej. Wśród szkoleń o tematyce środowiskowej były takie propozycje jak „ochrona środowiska w gospodarstwie rolnym, segregacja odpadów w gospodarstwie domowym, uprawa rzepaku źródłem energii odnawialnej”.

Tab. 2. Tematyka i liczba szkoleń przewidziana na luty 2007r. przez MODR, oddział Siedlce dla grnin powiatów garwolińskiego, tosickiego, mińskiego, siedleckiego, sokolowskiego, węgrowskiego (www modrmazowsze.pl)

\begin{tabular}{|c|c|c|c|c|c|c|}
\hline \multirow[b]{2}{*}{ Powiat } & \multirow{2}{*}{ 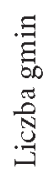 } & \multirow{2}{*}{ 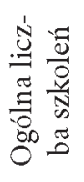 } & \multicolumn{4}{|c|}{ Tematyka i liczba szkoleń } \\
\hline & & & $\begin{array}{l}\text { Produkcja } \\
\text { rolnicza }\end{array}$ & $\begin{array}{c}\text { Rozwój obszarów } \\
\text { wiejskich i agro- } \\
\text { biznes }\end{array}$ & $\begin{array}{c}\text { Ochrona środowiska } \\
\text { w rolnictwie }\end{array}$ & $\stackrel{\circlearrowright}{\Xi}$ \\
\hline Łosicki & 6 & 12 & 3 & 5 & 4 & - \\
\hline Siedlecki & 13 & 30 & 12 & 6 & 8 & 4 \\
\hline Sokołowski & 8 & 10 & 3 & 4 & 3 & - \\
\hline Garwoliński & 11 & 10 & 4 & 3 & 3 & - \\
\hline Mińsk Maz & 11 & 21 & 2 & 13 & 4 & 2 \\
\hline Węgrowski & 9 & 16 & 4 & 5 & 6 & 1 \\
\hline Ogólem & 58 & 99 & 28 & 36 & 28 & 7 \\
\hline
\end{tabular}


Edukacja ustawiczna rolników jest szczególnie potrzebna w okresie przemian w tej gałęzi gospodarki. Pewnej grupie rolników pozwoli ona uczestniczyć w tych przemianach, innej pomoże je zaakceptować lub przynajmniej dostrzec ich potrzebę (Perepeczko, 2000). Okres dużych zmian zachodzących obecnie w gospodarstwach indywidualnych, wdrażających programy rolno-środowiskowe, ma zmodyfikować sposób podejścia rolników do ich obowiązków rozumianych jako starania o jakość i ilość plonów przy jednoczesnym minimalizowaniu negatywnych skutków tej działalności dla środowiska.

Wdrażanie polityki ekologicznej odbywa się za pomocą instrumentów oddziaływania bezpośredniego - przepisów prawnych wyznaczających działania dozwolone i niedozwolone wraz ze sposobami kontroli oraz pośredniego - oddziaływującego poprzez system zachęt (Giordano, 2005). Instrumenty zewnętrzne powinny z jednej strony utrudniać zachowania o negatywnym wpływie na środowisko, zaś z drugiej skłaniać ku pozytywnym praktykom prośrodowiskowym. Pożądane zachowania prośrodowiskowe, początkowo wymuszone czy sprowokowane, np. pomocą finansową w postaci dopłat, po jakimś czasie mogą stać się nawykiem, powszechnie interpretowanym jako wysoka świadomość ekologiczna danej grupy społecznej.

Do niektórych narzędzi polityki ekologicznej należą m.in.: specjalistyczna i powszechnie dostępna informacja oraz tworzenie przez gminę opracowań ekorozwojowych takich jak: strategia rozwoju gminy, program ochrony środowiska gminy, plan gospodarki odpadami, inwentaryzacja przyrodnicza gminy, studium zagospodarowania przestrzennego. Takie programy zamieszczone $w$ internecie dają możliwość wygodnego, swobodnego i nieograniczonego dostępu do informacji dotyczących spraw gminy, w tym także zapoznania się ze stanem oraz potrzebami środowiska i dzięki temu mogą stać się ważnym elementem edukacji ekologicznej społeczeństwa.

Edukacją ekologiczną mieszkańców wsi zajmują się parki krajobrazowe, które mogą w wydawanych opracowaniach własnych czy na stronach internetowych zamieszczać informacje oraz artykuły kształtujące ogólnie pojętą świadomość ekologiczną. Przypomnieć warto, że parki krajobrazowe są jedną z trzech form zapisanych w polskim prawie ochrony przyrody, które realizują ochronę w warunkach produkcyjnych, kierując się konstytucyjną zasadą zrównoważonego rozwoju. Jako przykład można podać to, że na stronie internetowej Nadbużańskiego PK można znaleźć informację o takich programach, jak np.: „Jak samemu zredukować emisję CO2? Wyłączaj! Oszczędzaj! Odzyskuj! Idź pieszo! Zmieniaj!” (www.npk.pl). Partnerem parku krajobrazowego w działaniach promujących ochronę przyrody i środowiska mogą być towarzystwa przyrodnicze. Badania stron internetowych wskazują na istnienie takiego partnerstwa w przypadku Nadbużańskiego PK i Parku Krajobrazowego Podlaski Przełom Bugu oraz Towarzystwa Przyrodniczego „Bocian”. Współpraca ta przynosi dobre efekty 
w edukacji wiejskiego społeczeństwa i skutkuje np. w postaci uchwalania przez rady gmin użytków ekologicznych czy pomników przyrody. Ważny jej element stanowi nawiązanie współpracy ze społecznością lokalną oraz motywowanie do aktywnej ochrony zamieszkiwanych terenów poprzez realizację programów rolno-środowiskowych w nadbużańskim krajobrazie.

Edukację prośrodowiskową $\mathrm{w}$ formie popularyzacji tematyki przyrodniczej, środowiskowej, regionalnej, geograficznej i zdrowotnej prowadzi także lokalna prasa. Współpracując z pracownikami gmin, może ona odegrać ważną rolę w kształtowaniu kultury ekologicznej rolników.

\section{Podsumowanie}

Rolnicy powinni mieć poczucie, że są przyrodnikami odpowiadającymi za trwałe funkcjonowanie ich gospodarstwa $\mathrm{z}$ zachowaniem wysokich parametrów jakościowych gleby, wód powierzchniowych, czystości i ładu w miejscowym krajobrazie. Zobowiązuje ich do tego szczególna odpowiedzialność, jaka wynika z troski o zdrowie i bezpieczeństwo konsumentów, na usługi których pracują, zarabiając na swoje utrzymanie. Kierując się zasadą zrównoważonego rozwoju, przestrzegając zasad dobrej praktyki rolniczej, a przede wszystkim szanując swoją godność, rolnicy mogą osiągać rozwój swoich gospodarstw, przyczyniając się jednocześnie do ochrony naszego przyrodniczego dziedzictwa. Kluczową sprawą w dążeniu do takiego ideału wiejskiej rzeczywistości jest dobrze zorganizowana edukacja, dostarczająca z jednej strony rzetelnej wiedzy o środowisku i jego wartości, a z drugiej strony kształtująca umiejętności i pożądane postawy. Oprócz etapu szkolnego, formalnego, jaki przechodził każdy rolnik przygotowujący się do prowadzenia gospodarstwa, ważne zadanie ma do spełnienia edukacja nieformalna, prowadzona przez różne podmioty odpowiedzialne za upowszechnianie wiedzy, w tym urzędy gminne. Pracujący w nich specjaliści powinni organizować szkolenia, konkursy, pokazy, wystawy, zapewniając sobie bezpośredni kontakt z osobami prowadzącymi gospodarstwa, ale także nie mogą zapominać o działaniach pośrednich, równie skutecznych, np. z wykorzystaniem internetu. Korzystnym rozwiązaniem byłoby, aby w każdej gminie powstał program edukacji ekologicznej, który pozostając w zgodzie z Polityką Ekologiczną Państwa uwzględniałby specyfikę społeczno-przyrodniczą regionu i koordynował działania lokalnie działających instytucji realizujących statutowe cele z obszaru ochrony przyrody i zrównoważonego rozwoju. Internet jako nowoczesne, szybkie i powszechnie dostępne medium informacyjne powinien być lepiej wykorzystany w przyrodniczej i sozologicznej edukacji środowiskowej gminnych społeczności. O tym, że tak na razie nie jest przekonują wyniki przeprowadzonych badań. 


\title{
Literatura
}

BĄKOWSKI J., 1999: Ekologiczna i integrowana produkcja warzyw w świetle dyrektywy Unii Europejskiej. W: Jabłońska Ceglarek R., [red.]: Proekologiczne metody uprawy warzyw. Zeszyty Problemowe Postępów Nauk Rolniczych, zeszyt 466. PWN, Warszawa.

Giordano K., 2005: Planowanie zrównoważonego rozwoju gminy w praktyce. Lublin, Wydawnictwo KUL.

KAWCZYŃsKi K., 2003: Budowa systemu selektywnej zbiórki i odzysku odpadów opakowaniowych w Polsce, Recykling 11.

Perepeczko B., 2000: Kierunki zmian w pozaszkolnej oświacie rolniczej. [W]Edukacja dorosłych. Teoria i praktyka w okresie przemian red. J. Saran, Lublin, Wydawnictwo UMCS.

Program Rozwoju Obszarów Wiejskich na lata 2007-2013, Ministerstwo Rolnictwa i Rozwoju Wsi.

Zwykła Dobra Praktyka Rolnicza. Ministerstwo Rolnictwa i Rozwoju Wsi. Departament Rozwoju Obszarów Wiejskich, Warszawa 2004.

www.bocian.org.pl

www. mazovia.pl - strona Samorządu Województwa Mazowieckiego

www.modr.mazowsze.pl - strona Mazowieckiego Ośrodka Doradztwa Rolniczego

www.npk.pl

www.podlaskiprzelombugu.pl

\section{Forming of ecological awareness of rural communities through the use of information by the local government}

\author{
SUMMARY
}

Access to information about the state of environment and action taken by local government on its behalf is an important element influencing participation of citizens of rural areas.

The aim of this research was to check if the local government of the chosen communes of East Mazowsze makes it possible for the citizens to gain access to information using the internet. 58 internet sites of the chosen communes of East Mazowsze were analysed. The research showed big differences in the use of internet as to the contents and technical abilities of said communes. They do not fully utilize the possibility to publish information on the internet and with that the ability to communicate with the others. 
Rys. 1. Struktura dzialań edukacyjnych kształtujących świadomość ekologiczną rolników

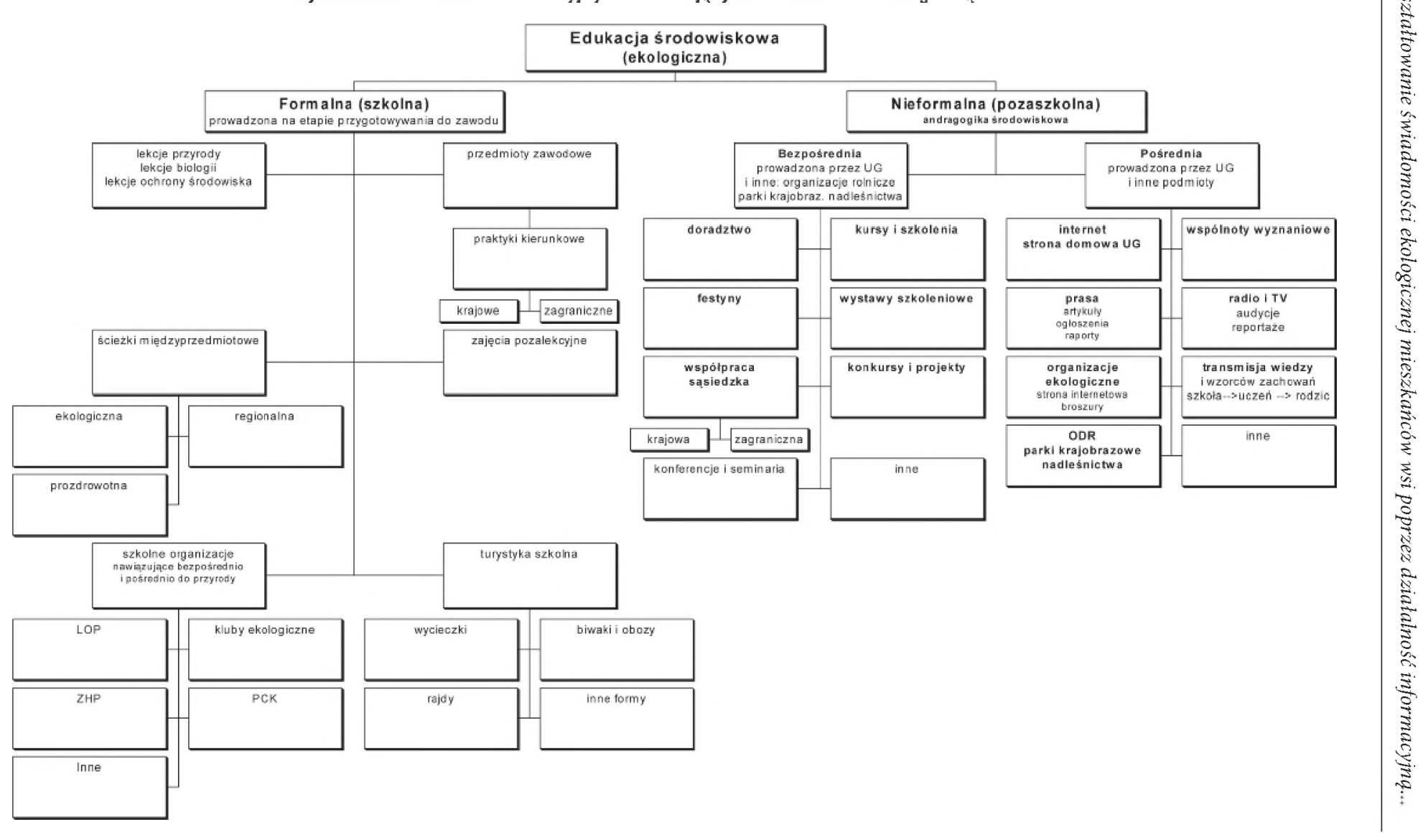

